\title{
THE WORDS "SUSPECT" AND "PATIENT": A CORPUS-BASED ANALYSIS OF SEMANTIC PROSODY IN COVID-19 CORPORA
}

\author{
Dhyan Purwitarini*
}

Linguistics Master's Program, Faculty of Humanities, Universitas Airlangga, Surabaya 60286, Indonesia

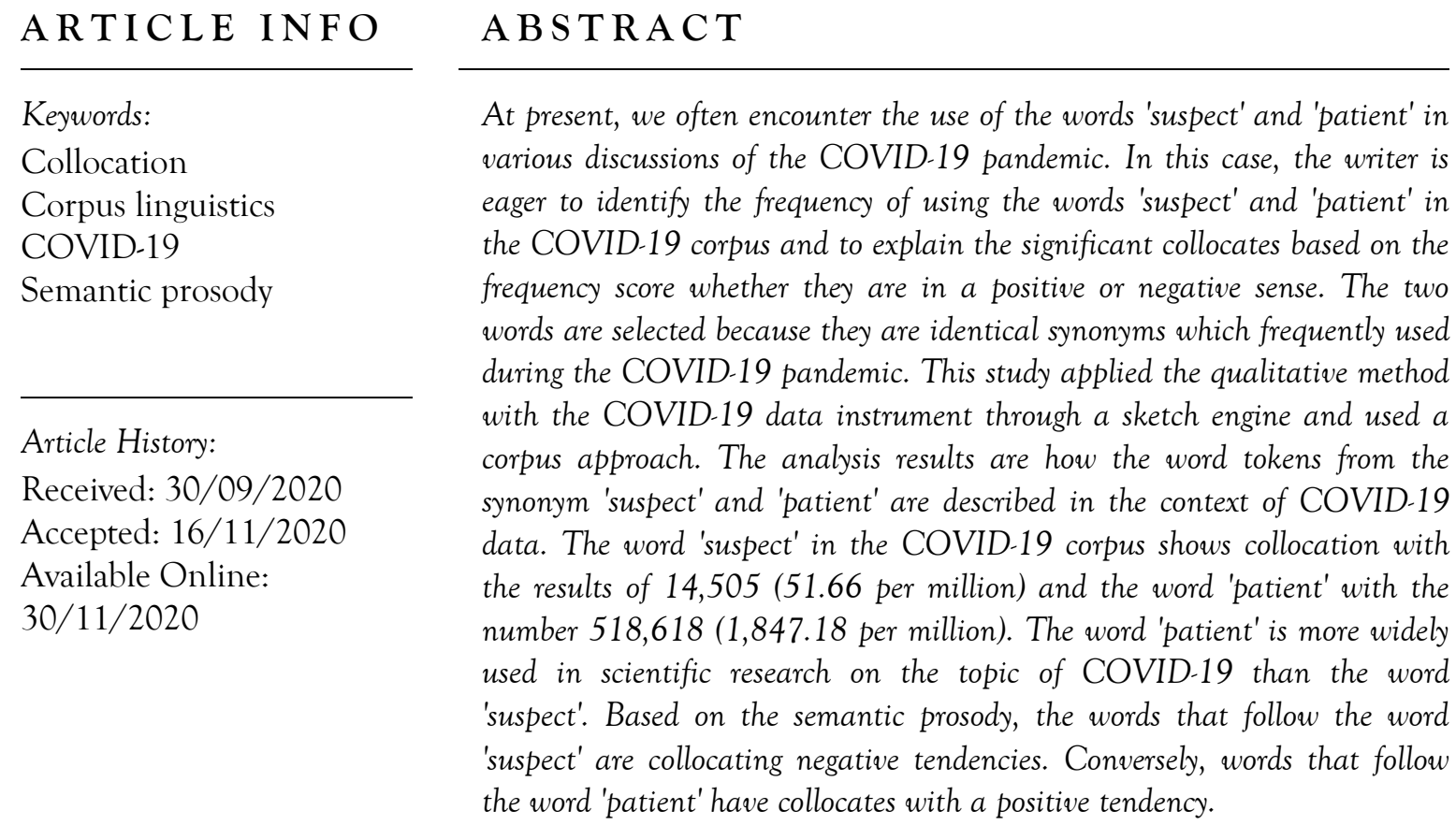

2442-305X / (C) 2020 The Author, this is open access article under the (CC-BY-NC) license (https://creativecommons.org/licenses/by-nc/4.0/), DOI: 10.19105/ojbs.v14i2.3846

\footnotetext{
* Corresponding Author:

Email address: dhyanpurwitarini@gmail.com (D. Purwitarini)
}

\section{A. Introduction}

Semantic studies have always experienced developments in their research because there are always challenges or problems that are studied by linguists. It indicates that this semantic field is still an area that is always ready to be explored by language activists. The subject of synonyms is included in the field of semantic studies which is still very open to continuous exploration related to linguistic research. Khazaal defined synonyms are words or phrases which have the same meaning as other words or phrases in the same language. ${ }^{1}$ Also,

1 Edhah Numan Khazaal, "Investigating and Analyzing ESP College Students' Errors in Using Synonyms," International Journal of English Linguistics 9, no. 5 (2019): 328-39, https://doi.org/10.5539/ijel.v9n5p328. 
synonym itself is an important and complex linguistic feature. ${ }^{2}$ Synonyms included a vital part of precise and effective communication to simultaneously challenge the language users. ${ }^{3}$

Language users have a set of mental rules resulting from the priming process, integrated mental lexicons, and collocation of items. ${ }^{4} \quad$ Including comprehension of vocabularies, language users understand that synonyms have a lot in common. Synonyms are usually used to express similarity in meaning. Stojchevska explained in a detailed way about Novikov who was the first person making an attempt to classify synonyms. ${ }^{5}$ She added that Novikov classified the synonyms into two, which are the complete interchangeableness and partial interchangeableness.

There are two aspects of interchangeableness: the number of contexts and the degree of success of using the words. $^{6}$ Meanwhile, partial

\footnotetext{
${ }^{2}$ Millatul Islamiyah and Muchamad Sholakhuddin Al Fajri, "Skinny, Slim, dan Thin: Analisis Berbasis Korpus Kata Sifat Identik dan Implikasinya pada Pengajaran Bahasa Inggris," Ranah: Jurnal Kajian Bahasa 8, no. 1 (2019): 19-32, https://doi.org/10.26499/rnh.v8i1.894.

3 Evelyn Hatch and Cheryl Brown, Vocabulary, Semantics and Language Education (Cambridge: Cambridge University Press, 1995), 19-20.

${ }^{4}$ Alan Partington, "'Utterly Content in Each Other's Company': Semantic Prosody and Semantic Preference," International Journal of Corpus Linguistics 9, no. 1 (2004): 131-56, https://doi.org/10.1075/ijcl.9.1.07par.

${ }^{5}$ Bisera Kostadinovska Stojchevska, "The Semantic Aspect of the Acquisition of Synonyms, Homonyms and Antonyms in the Teaching Process of English as A Foreign Language," European Journal of Foreign Language Teaching 3, no. 2 (2018): 30, https://doi.org/10.5281/zenodo.1216500.

${ }^{6}$ Stojchevska, 30.
}

synonymy relates to the meaning components. $^{7}$

The expression of the same meaning is because several sets of words that are encountered can have the same and similar meanings or it can be said that the relationship between these words is similar. The words that make up this collection are called synonymous pairs. ${ }^{8}$ From this matter, synonym pairs can consist of two or more words. In semantic networks, the words are indicated as connected nodes to other words in the network by some relations. ${ }^{9}$

On the other hand, two synonymous words cannot always deliver the exact same meaning or connotation. ${ }^{10}$ Synonyms that are considered absolute are very rare. In fact, Edmonds and Hirst said that the sensitivity of words will continue to change, native language tends to eliminate absolute synonyms. ${ }^{11}$ This was emphasized by Collinson's statement that the similarity in meaning of linguistic forms from one another could be that each word has certain nuances of difference. ${ }^{12}$ Therefore, in their research,

\footnotetext{
${ }^{7}$ W. V. Quine, "Main Trends in Recent Philosophy: Two Dogmas of Empiricism," The Philosophical Review 60, no. 1 (1951): 20-43, https://doi.org/10.2307/2181906.

8 Utami Retno, "Kajian Sinonim Nomina dalam Bahasa Indonesia" (Master Thesis, Universitas Sebelas Maret Surakarta, 2010), 19.

9 David W. Carroll, Psychology of Language (Belmont: CA: Thomson Learning Academic Resource Center, 2008), 110.

${ }^{10}$ Islamiyah and Fajri, "Skinny, Slim, dan Thin," 20.

11 Philip Edmonds and Graeme Hirst, "NearSynonymy and Lexical Choice," Computational Linguistics 28, no. 2 (2002): 105-44, https://doi.org/10.1162/089120102760173625.

12 Collison in Retno, "Kajian Sinonim Nomina Dalam Bahasa Indonesia," 21.
} 
Storkel and Maekawa represented semantics in learning that synonyms can facilitate in words or vocabularies comprehension by decreasing cognitive demands just the way the words mean rather equal in synonym pairs. ${ }^{13}$

The concept of semantic prosody is related to experts' thinking, such as connotation by Stubbs, ${ }^{14}$ attitude of meaning explained by Sinclair, ${ }^{15}$ or evaluative meaning by Hunston. ${ }^{16}$ Sinclair stated that certain words and phrases tend to occur in certain semantic environments. ${ }^{17}$ Then, it became popular and it was introduced by Bill Louw. ${ }^{18} \mathrm{He}$ revealed that semantic prosody had functioned as a soul of meaning with which the collocated form is imbued

13 Holly L. Storkel and Junko Maekawa, "A Comparison of Homonym and Novel Word Learning: The Role of Phonotactic Probability and Word Frequency," Journal of Child Language 32, no. 4 (2005): 827-53.

${ }^{14}$ Michael Stubbs, Words and Phrases: Corpus Studies of Lexical Semantics (Oxford: Blackwell Publishing, 2001), 96.

15 John Sinclair, "The Search for Units in a Meaning," Textus IX, 1996, 94.

16 Hunston as quoted by Natalie Kübler and Alexandra Volanschi, "Semantic Prosody and Specialised Translation, or How a Lexico Grammatical Theory of Language Can Help with Specialised Translation," in Studies in Corpus Linguistics, ed. Alex Boulton, Shirley CarterThomas, and Elizabeth Rowley-Jolivet, vol. 52 (Amsterdam: John Benjamins Publishing Company, 2012), 2, https://doi.org/10.1075/scl.52.05kub.

17 John M. Sinclair, Looking Up: An Account of the COBUILD Project in Lexical Computing (London and Glasgow: HarperCollins, 1996), 112.

${ }^{18}$ Bill Louw, "Irony in the Text or Insincerity in the Writer? - The Diagnostic Potential of Semantic Prosodies," in Text and Technology, ed. Mona Baker, Gill Francis, and Elena Tognini-Bonelli (Amsterdam: John Benjamins Publishing Company, 1993), 157, https://doi.org/10.1075/z.64.11lou. with. ${ }^{19}$ Hunston added that the word appears together with other words that belong to a certain semantic set and then they have certain semantic prosody. ${ }^{20}$

In his book, Sinclair divided types of the connection between lexical units that include collocation, semantic prosody, and semantic preference. ${ }^{21}$ Michael Stubbs examined that semantic preference acts as a relationship not only between individual words but between lemmas or tenses. ${ }^{22}$ It includes a set of words that are semantically related. Semantic preference is often related to the concept of collocation. ${ }^{23}$ Likewise, this has to do with semantic prosody which describes a speaker's evaluative attitude. Louw in the Salama quoted that the term of semantic prosody is the meaning of words that are understood through their collocation and often offers ideas about implicit meanings. ${ }^{24}$ Louw also added that there are words also included in negative semantic prosody because they often collaborate with words that have negative meanings.

\footnotetext{
${ }^{19}$ Louw, 157.

${ }^{20}$ Susan Hunston, Corpora in Applied Linguistics, Cambridge Applied Linguistics (Cambridge: Cambridge University Press, 2002), https://doi.org/10.1017/CBO9781139524773.

${ }^{21}$ John Sinclair, "The Lexical Item.-Edda Weigand (Ed.). Contrastive Lexical Semantics. Current Issues in Linguistic Theory 171" (Amsterdam: John Benjamins, 1998), 1-24.

${ }^{22}$ Stubbs, Words and Phrases, 65.

${ }^{23}$ Amir H. Y. Salama, "Ideological Collocation and the Recontextualization of Wahhabi-Saudi Islam Post-9/11: A Synergy of Corpus Linguistics and Critical Discourse Analysis," Discourse \& Society 22, no. 3 (2011): 315-42, https://doi.org/10.1177/0957926510395445.

${ }^{24}$ Salama, 320.
} 
Here, the corpus becomes a reference for a collection of texts that emerge naturally from various spoken and written contexts. ${ }^{25}$ Corpus research is widely used to complement the methodology in the study of linguistic variation. Its quantitative methods are innovative and are quickly becoming popular in various branches of language analysis. Corpus linguistics can and has been used to complement both discourse analysis in Applied Linguistics the "noncritical" discourse analysis used in language teaching) and Critical Discourse Analysis which aims to reveal ideological biases based on synchronic studies of lexical patterns. ${ }^{26}$

Thus, the approach taken uses a synchronic-dominated corpus in text analysis which states a close relationship between shared text and context. ${ }^{27}$ This relationship between shared texts and context is important for studying the language of a particular discourse, and also allows comparisons between discourses, because the same words and expressions in the same language can have different semantic value for people from different discourse communities. By comparing the ways the discourse community uses corpora-based language specifically designed for that purpose, particularly with respect to the lexical

${ }^{25}$ Anne O'Keeffe, Michael McCarthy, and Ronald Carter, From Corpus to Classroom: Language Use and Language Teaching (Cambridge: Cambridge University Press, 2007), 27.

${ }^{26}$ Nelya Koteyko, "Corpus Linguistics and the Study of Meaning in Discourse," The Linguistics Journal 1, no. 2 (2006): 132-57.

${ }^{27}$ Koteyko, 149. choices they make, corpus linguists have a good idea of what makes their language ideological.

Starting from the end of 2019 to now July 2020 , we have been alarmed by the coronavirus outbreak. In December 31, 2019, WHO China Country Office was informed of cases of pneumonia unknown etiology (unknown cause) detected in Wuhan City, Hubei Province of China. A total of 44 case-patients with pneumonia unknown etiology which then identified as COVID-19 (2019-Ncov). They were 282 confirmed cases by January 20, 2020. ${ }^{28}$ It confirmed China as the country that first reported cases of COVID-19 in the world.

University College London Genetics Institute conducted a study showing that COVID-19 has infected humans since the end of 2019. ${ }^{29}$ This matter was proven after researching the Coronavirus which was taken from more than 7,600 patients around the world. The researchers looked at various samples from different times and places. The results show that the Coronavirus has infected the first person at the end of 2019.

Starting at the time of Corona Virus Disease 2019 (COVID-19) at the end of 2019, this virus was declared a pandemic by WHO on March 11, 2020 and the discovery of positive cases of COVID-19

\footnotetext{
${ }^{28}$ World Health Organization, "Novel Coronavirus (2019-NCOV)," Situation Report, January 20, 2020, 1 , https://www.who.int/docs/defaultsource/coronaviruse/situation-reports/20200121sitrep-1-2019-ncov.pdf.

${ }^{29}$ University College London, "Mutations in SARSCoV-2 Offer Insights into Virus Evolution," UCL News, May 6, 2020, https://www.ucl.ac.uk/news/2020/may/mutationssars-cov-2-offer-insights-virus-evolution.
} 
in Indonesia, the public has been urged to remain calm and adopt healthy living habits. We must ensure our own safety by washing our hands regularly with soap and running water. In addition, people who are in charge of caring for people with respiratory illness or people who have respiratory symptoms (coughing or sneezing) are advised to wear a mask to limit the spread of this respiratory disease.

This Coronavirus is a topic that is always discussed, especially in the academic world. Researchers in the world have continuously researched COVID-19. The COVID-19 tagline is engraved on every search page for scientific journals. COVID-19 is researched from all branches of education. Not only discussed in the medical world, but COVID-19 is also discussed in the scope of language. This matter is the writer's interest in discussing how people from academia choose the words or terms related to critical matters that have not even found a vaccine until now regarding language. Furthermore, the writer intends to examine how the similarities of the nouns 'suspect' and 'patient' are included in scientific sentences discussing COVID-19.

In this case, the author includes several studies with a similar concept to lead the author to research this study. The first study was written by Sylvia Jaworska and Kath Ryan with the title "Gender and the language of pain in chronic and terminal illness: A corpus-based discourse analysis of patients' narratives". ${ }^{30}$ This

${ }^{30}$ Sylvia Jaworska and Kath Ryan, "Gender and the Language of Pain in Chronic and Terminal Illness: A Corpus-Based Discourse Analysis of Patients' study explained how women and men use language to do person-in-pain in real-life interactions regarding chronic and terminal illnesses. The authors identified sixteen chronic and terminal conditions in which men and women talked about physical pain. They used the linguistic approach of corpus-assisted discourse analysis to examine the narratives of men and women. The study showed that there were significant quantitative and qualitative differences when women and men report pain. It pointed to the existence of distinctive feminine and masculine lexical repertoires of pain talk.

There was also research entitled "How seemingly innocuous words can bias judgment: Semantic prosody and impression formation" written by David J. Hauser and Norbert Schwarz. ${ }^{31}$ This study investigated the negative context of the word choices between "caused" and "utterly" compared to the words "produced" and "totally" towards language used by person descriptors. Five studies pointed out that semantically-prosodic descriptors affect the impressions formed of others. These effects occur where perceivers are likely to be skeptical of messages, and they impact behavioral intentions toward targets. Based on the two journals, it was found that different

Narratives," Social Science \& Medicine (1982) 215 (2018):

107-14,

https://doi.org/10.1016/j.socscimed.2018.09.002.

31 David J. Hauser and Norbert Schwarz, "How Seemingly Innocuous Words Can Bias Judgment: Semantic Prosody and Impression Formation," Journal of Experimental Social Psychology 75 (2018): $11-18$

https://doi.org/10.1016/j.jesp.2017.10.012. 
studies were found in different contexts, different aims, and the different corpora used. The author's purposes in conducting this research are to identify the frequency of using the words 'suspect' and 'patient' in the COVID-19 corpora and to explain the significant collocates based on the frequency score whether they are in positive or negative sense.

\section{B. Method}

The corpus is an innovative method in studying various studies, including linguistic studies. As a methodology, the main characteristics of the linguistic corpus are in its empirical approach, focusing on authentic approaches, meaningful approaches, and the use of digital tools to process language data in order to obtain objective results. However, the results that have been processed from this corpus still need to be interpreted. When the data had been conducted interpretation, then it was when the theory and guidance of the linguistic hypothesis were needed. ${ }^{32}$ The principle in conducting collocation analysis is to extend the analysis beyond one or two words, or even also syntactic patterns. ${ }^{33}$ The writer concerned to the pervasiveness of semantic prosody in two terms of COVID-19 "suspect" and "patient". The use of corpus on semantic

\footnotetext{
${ }^{32}$ Hunston, Corpora in Applied Linguistics, 38.

33 Dylan Glynn, "Techniques and Tools: Corpus Methods and Statistics for Semantics," in Corpus Methods for Semantics: Quantitative Studies in Polysemy and Synonymy, ed. Dylan Glynn and Justyna A. Robinson (Amsterdam: John Benjamins Publishing Company, 2014), 307, https://benjamins.com/catalog/hcp.43.
}

profiles examined evaluative features that language users may not always be aware of because these words are not yet part of the dictionary information. ${ }^{34}$

This study used the user-friendly Sketch Engine web service (hereinafter SkE) as a data analysis instrument. The Sketch Engine web service was a leading and widely used corpus tool within the lexicography sphere. The machinereadable corpora allow such a study to be systematic. $^{35}$ The Sketch Engine website offered many ready-to-use corpora, and tools for users to build, upload, and install their own corpora. Sketch Engine provided several main functions: concordance, collocation, thesaurus, word sketch and more. For this study, only the concordance, collocation, and text types were used by the researcher.

In this study, it used the COVID-19 corpus data from the sketch engine. The researcher accessed it via https://www.sketchengine.eu/ with the word 'suspect' and the word 'patient'. In the first phase, the author opened the corpus tool named Sketch Engine to get text corpora. Based on the aim of the study which intended to examine two words in the COVID-19 pandemic, the author specified the search for corpora, namely COVID-19. The author typed

\footnotetext{
${ }^{34}$ Helle Dam-Jensen and Karen Korning Zethsen, "Translator Awareness of Semantic Prosodies," Target. International Journal of Translation Studies 20, no. 2 (2008): 203-21, https://doi.org/10.1075/target.20.2.02dam.

35 Soili Nokkonen, "The Semantic Variation of NEED TO in Four Recent British English Corpora," International Journal of Corpus Linguistics 11, no. 1 (2006):

29-71,

https://doi.org/10.1075/ijcl.11.1.03nok.
} 
"COVID-19" in the corpus search field on Sketch Engine. These COVID-19 corpora data came from texts that were released as part of the COVID-19 Open Research Dataset (CORD-19), as well as the references are COVID-19 Open Research Dataset (CORD-19) in 2020. Then, the writer typed the word "suspect" in the search column for Concordances. The Concordance menu in Sketch Engine was "a tool with a variety of search options. It searches words, phrases, tags, documents, text types, or corpus structures and displays the results in context in the form of a concordance. The concordance can be sorted, filtered and processed further to obtain the desired result". It appeared with the originial output from Sketch Engine as in Table 3. in result section of this study. The doi.org column itself was described in Sketch Engine as being derived from metadata.

The next step was to click on the option with a symbol like "...". The menu was to determine the collocation in the word "suspect". In Sketch Engine, it was described that "the collocation tool uses the traditional approach to identify collocations. It is not as advanced as the word sketch which is the preferred option especially for single words or combinations of a node and collocate (s). It also scans. the specified span to the right and / or left of KWIC and calculates a selection of statistical measures to identify collocations." The display itself consisted of a span from the left position -5, -4, -3, 2, -1, KWIC, +1, +2, +3, +4, +5. KWIC stood for "Key Word In Context". The author chose the span -5 on the left and
+5 on the right so that the data obtained were even wider in scope. After that, a list of words were collocated "suspect" appeared and the writer chose a few words that fulfilled the criteria most often following the word "suspect" as 'nouns modified suspect / patient'. This description of 'nouns modified suspect / patient' itself can be done before identifying collocations in the Concordance menu by determining them in the Word Sketch Difference menu. This series of data collection was also applied when identifying collocations in the word "patient".

$\begin{array}{ccc}\text { The author conducted a } & \\ \text { concordance analysis based on }\end{array}$
synonymous nouns. The two words will then be analyzed based on their collocation. This collocation analysis was carried out to obtain information about semantic preferences or lexical patterns of each adjective. Then, in the discussion, it will be discussed further regarding the interpretation of these two synonymous nouns.

\section{Results}

The keywords contained in this study are the significant collocations in 'suspect' and 'patient' by using collocations span of -5 and +5 . The author chooses the span -5 on the left and +5 on the right so that the data obtained is even wider in scope. The following word results are in the table below. 
Table 1.

The Collocation of the word "Suspect"

\begin{tabular}{lllll}
\hline & Collocate & Coocurances & T-score & MI \\
\cline { 2 - 5 } Suspect & SARS & 517 & 22.53 & 6.77 \\
$\mathbf{1 , 4 0 3}$ (freq) & Case-patients & 31 & 5.55 & 8.16 \\
& Malaria & 52 & 7.10 & 6.04 \\
& Animal & 95 & 9.31 & 4.47 \\
& Cat & 57 & 7.42 & 5.86 \\
\hline
\end{tabular}

Table 2.

The Collocation of the word "Patient"

\begin{tabular}{|c|c|c|c|c|}
\hline & Collocate & Coocurances & T-score & MI \\
\hline & Care & 12,877 & 112.02 & 6.28 \\
\hline Patient & Safety & 2,055 & 44.14 & 5.25 \\
\hline \multirow[t]{3}{*}{32,963 (freq) } & Management & 3,782 & 60.21 & 5.58 \\
\hline & Outcome & 2,530 & 49.21 & 5.53 \\
\hline & Contact & 4,526 & 65.59 & 5.32 \\
\hline
\end{tabular}

Based on the tables above, the word 'suspect' has a frequency of 1.403 . Then, five lemmas are identified as the most identical in collaboration with the word 'suspect'. The five words consist of SARS, case-patients, malaria, animal, and cat. The first collocation that appears together with 'suspect' in a specific sentence structure is the word 'SARS' of 517, the word 'case-patients' is 31 , 'malaria' is 52, 'animal' is 95 and 'cat' is 57. For the number contained in the $T$ Score in the word 'SARS' was 22.53; the word for 'case-patients' was 5.5; 'malaria' by 7.10; 'animal' is 9.31 and 'cat' is 7.42 . Meanwhile, the amount of mutual information (MI) in the word 'SARS' was 6.77; the word 'case-patients' is 8.16 ; 'malaria' by 6.04 ; 'animal' at 4.47 ; and 'cat' of 5.86 .

Meanwhile, the word 'patient' has an occurrence frequency of 32,963 times. There are five lemmas that are most identically collocated with the word patient. The five words consist of care, safety, management, outcome, and contact. The first collocation that appears together with 'patient' in a certain sentence structure is the word 'care' of 12,877 , the word 'safety' is 2,055 , the word 'management' is 3,782 , 'outcome' is 2,530 and 'contact' is 4,526. For the number contained in the T-Score in the word 'care' was 112.02, the word 'safety' was 44.14, the word 'management' was 60.21, the word 'outcome' was 49.21 and 'contact' was 65.59. Meanwhile, the number of mutual information (MI) in the word 'care' was 6.28, in the word 'safety' it was 5.25 , the word 'management' was 5.58, the word 'outcome' was 5.53 and 'contact' amounting to 5.32. The collocation of the word 'suspect' shows a result of 14,505 (51.66 per million) and the word 'patient' has a result of 518,618 (1,847.18 per million). 
The author analyzed this problem for the collocation with the highest frequency combination of the words 'suspect' and 'patient' from the respective contexts as follows.

From the data results, the collocate which often appears following the word 'suspect' is 'SARS'. The collocate SARS that follows the word 'suspect' is based on a meaning relation called semantic prosody. Semantic prosody itself is the relationship between nodes and their collocation. This then has a meaningful relationship in the semantic field. According to Hauser and Schwarz, in their views on previous studies, ${ }^{36}$ Semantic prosody leads to evaluative judgments. They added that although words with semantic prosody are often judged to be neutral in valence, in their research, they emphasized that how words typically used are influenced by people's impressions and how they explain them can actually make it more negative or positive. ${ }^{37}$ It is in line with the result of this study that the collocate 'SARS' which follows the word 'suspect' below also has negative context. It is supported by the explanation or the description of the word 'suspect' in the Oxford Dictionary. It is said that the origin of the word 'suspect' itself is Middle English (originally as an adjective): from Latin suspectus 'mistrusted', past participle of suspicere, from sub- 'from below' + specere 'to look'. It means that 'suspect' itself comes from the Latin word suspectus which refers to the adjective 'not to believe'.

This matter further strengthens the idea that 'suspect' has a negative meaning in its semantic prosody. It can be seen from the collocations that have a high frequency when juxtaposed with the 'suspect'. Collocation of 'suspect' itself relates to animals and diseases and viruses and 1 word is 'case-patient'. This indicates that there is a patient specification, namely the fileus patient.

The ten samples of the collocation of 'SARS' which follows the word 'suspect' are presented in table 3. That table proves that the collocate 'SARS' which follows the word 'suspect' has a negative meaning seen from a certain arrangement in the context of existing sentences in scientific journals from the corpus COVID-19. From the ten samples, the collocation of 'suspect' followed by 'SARS', almost all of them indicate that patients who have a dangerous disease or are diagnosed with the SARS virus. In fact, there are several words about the patient before the word 'suspect', but this refers more to people who are suspected or have a tendency to have the virus in their body.

\footnotetext{
36 Hauser and Schwarz, "How Seemingly Innocuous Words Can Bias Judgment," 12.

${ }^{37}$ Hauser and Schwarz, 12.
} 
Table 3.

The collocation of 'SARS' which follows the word 'suspect'

\begin{tabular}{|c|c|c|c|c|}
\hline No. & $\begin{array}{l}\text { Details of } \\
\text { source }\end{array}$ & Left Context & KWIC & Right Context \\
\hline 1. & doi.org & $\begin{array}{r}\text {...they are maintaining and } \\
\text { repairing equipment that has been } \\
\text { used on-or that has been in the } \\
\text { same room as-patients who have } \\
\text { or who are }\end{array}$ & suspected & $\begin{array}{l}\text { of having SARS. For the most part, } \\
\text { these represent good infection } \\
\text { control practices that should be } \\
\text { followed when servicing any } \\
\text { device... }\end{array}$ \\
\hline 2. & nih.gov & $\begin{array}{r}\text { The main outcome measure was } \\
\text { daily number of isolation beds } \\
\text { occupied by SARS patients, } \\
\text { including those fulfilling WHO } \\
\text { criteria for }\end{array}$ & suspected & $\begin{array}{l}\text { and probable SARS [16], as well } \\
\text { as those admitted not fulfilling WHO } \\
\text { case definitions but admitted to } \\
\text { isolation rooms for observation. }\end{array}$ \\
\hline 3. & nih.gov & $\begin{array}{r}\text { The effect on bedside practice was } \\
\text { difficult to evaluate properly } \\
\text { because only one cardiac arrest } \\
\text { actually occurred in a patient }\end{array}$ & suspected & $\begin{array}{l}\text { of having SARS. We describe the } \\
\text { use of high-fidelity simulation to } \\
\text { design a modified practice of } \\
\text { cardiac arrest resuscitation for an } \\
\text { 'at risk of contamination'... }\end{array}$ \\
\hline 4. & nih.gov & $\begin{array}{r}\text { We cannot validate the efficacy of } \\
\text { our teaching because only one } \\
\text { cardiac arrest occurred in the } \\
\text { hospital in a patient }\end{array}$ & suspected & $\begin{array}{l}\text { to have SARS. } 1054 \text { Question } 1 \\
\text { was asked of all participants; } \\
\text { questions } 2 \text { and } 3 \text { were added later. }\end{array}$ \\
\hline 5. & nih.gov & $\begin{array}{r}\text { When Hospital A closed during the } \\
\text { SARS outbreak, a second hospital } \\
\text { (Hospital B) was designated to } \\
\text { care for }\end{array}$ & suspect & $\begin{array}{l}\text { SARS cases. There were no SARS } \\
\text { cases among staff at Hospital B, } \\
\text { and a serosurvey conducted among } \\
\text { workers at the facility revealed no } \\
\text { inapparent or asymptomatic } \\
\text { infections... }\end{array}$ \\
\hline 6. & nih.gov & $\begin{array}{r}\text { The clinical case definition of } \\
\text { probable SARS included a fever of } \\
\geq 38^{\circ} \mathrm{C} \text {, cough or shortness of } \\
\text { breath, new pulmonary infiltrates } \\
\text { on chest radiography, and close } \\
\text { contact with a }\end{array}$ & suspect & $\begin{array}{l}\text { or probable SARS case. Day } 1 \text { was } \\
\text { defined as the day of fever onset. }\end{array}$ \\
\hline 7. & nih.gov & $\begin{array}{r}\text { In Hong Kong, a total of } 384 \\
(22.1 \%) \text { of } 1739\end{array}$ & suspected & $\begin{array}{l}\text { or confirmed SARS patients were } \\
\text { hospital workers. }\end{array}$ \\
\hline 8. & nih.gov & $\begin{array}{l}\text { From source public health records, } \\
\text { we extracted data for all } 332 \text { index } \\
\text { cases with a final disposition of }\end{array}$ & suspected & $\begin{array}{l}\text { or probable SARS [23] of whom } \\
204 \text { had at least one community } \\
\text { contact uniquely associated with } \\
\text { them in Public Health records. }\end{array}$ \\
\hline 9. & nih.gov & $\begin{array}{l}\text { Table } 1 \text { summarizes quarantine } \\
\text { status for } 332 \text { probable and }\end{array}$ & suspected & $\begin{array}{l}\text { SARS cases in the } 2003 \text { Ontario } \\
\text { SARS outbreak, with numbers of } \\
\text { contacts by level of contact and } \\
\text { transmission status. }\end{array}$ \\
\hline 10. & nih.gov & $\begin{array}{r}\text {...additional } 140 \text { individuals who } \\
\text { were potential SARS cases at } \\
\text { some point during the outbreak } \\
\text { and had at least one community } \\
\text { contact, but subsequently did not } \\
\text { meet criteria for probable or }\end{array}$ & suspected & $\begin{array}{l}\text { SARS. } \ddagger \text { Includes } 8,498 \text { community } \\
\text { contacts with contact to one SARS } \\
\text { case... }\end{array}$ \\
\hline
\end{tabular}


Table 4.

The collocation of the word 'care' which follows the word 'patient'

\begin{tabular}{|c|c|c|c|c|}
\hline No. & $\begin{array}{l}\text { Details of } \\
\text { source }\end{array}$ & Left Context & KWIC & Right Context \\
\hline 1. & doi.org & $\begin{array}{r}\text { We thank all the medical and } \\
\text { nursing staff who assisted in the } \\
\text { care of }\end{array}$ & patients & $\begin{array}{l}\text {; the members from health } \\
\text { department and CDC in } \\
\text { Guangdong Province for their } \\
\text { contribution in data collection, } \\
2019-n \text { CoV control and prevention. }\end{array}$ \\
\hline 2. & doi.org & $\begin{array}{r}11 \text { Local health care practices and } \\
\text { non-formal healthcare systems } \\
\text { also } 58 \text { provide care to }\end{array}$ & patients & $\begin{array}{l}\text { during epidemics and can play a } \\
\text { part in quarantining infected } 59 \\
\text { individuals. }\end{array}$ \\
\hline 3. & doi.org & $\begin{array}{l}\text { Since the urinary system infection } \\
\text { and its potential aftermath could } \\
\text { be essential to the }\end{array}$ & patient & $\begin{array}{l}\text { care during and after the infection, } \\
\text { here we used two scRNA-Seq } \\
\text { transcriptome data in healthy } \\
\text { kidneys and one dataset in heathy } \\
\text { bladders to investigate the } \\
\text { expression patterns of cell types in } \\
\text { the urinary system. }\end{array}$ \\
\hline 4. & doi.org & The research showed that $26 \%$ of & patients & $\begin{array}{l}\text { received ICU care, and mortality } \\
\text { was } 4.3 \% \text {. }\end{array}$ \\
\hline 5. & doi.org & $\begin{array}{r}\text { Patients with age } \geq 50 \text { and NLR }< \\
3.13 \text { patients who are moderate } \\
\text { risk, should be admitted to } \\
\text { isolation ward with respiratory } \\
\text { monitoring and supportive care. }\end{array}$ & patients & $\begin{array}{l}\text { with age } \geq 50 \text { and NLR } \geq 3.13 \text { who } \\
\text { are high risk should actively transfer } \\
\text { to ICU... }\end{array}$ \\
\hline 6. & doi.org & $\begin{array}{l}\text {...even for the highly efficient } \\
\text { Chinese logistics that did manage } \\
\text { to build two new } 357 \text { hospitals in } \\
\text { record time to treat infected }\end{array}$ & patients & $\begin{array}{l}\text { Supportive care with extracorporeal } \\
358 \text { membrane oxygenation } \\
\text { (ECMO) in intensive care units } \\
\text { (ICUs) is critical for severe } 359 \\
\text { respiratory disease. }\end{array}$ \\
\hline 7. & doi.org & $\begin{array}{c}\ldots \text { it is necessary to explore the } \\
\text { mechanisms of abnormal renal } \\
\text { function and to promote to take } \\
\text { special care on such }\end{array}$ & patients & $\begin{array}{l}\text { As the virus frequently enters the } \\
\text { cell by binding to cell receptors, and } \\
\text { ACE2 has been proven to be one of } \\
\text { the major receptors of } 2019 \text {-nCoV } \\
\text { in human body,... }\end{array}$ \\
\hline 8. & doi.org & 2. $5 \%$ of COVID-19 & patients & need intensive care. \\
\hline 9. & doi.org & $\begin{array}{l}\text {....indicating that SARS-CoV-2 } \\
\text { viruses induce T cell exhaustion in } \\
\text { COVID-19 patients, particularly in } \\
\text { those requiring ICU care. Three }\end{array}$ & patients & $\begin{array}{l}\text { were follow-up during inpatient } \\
\text { care... }\end{array}$ \\
\hline 10. & doi.org & $\begin{array}{r}\text { presumed hospital-related } \\
\text { transmission of SARS-CoV-2 was } \\
\text { suspected in } 41 \% \text { of patients, } 26 \% \\
\text { of }\end{array}$ & patients & $\begin{array}{l}\text { received ICU care, and mortality } \\
\text { was } 4.3 \%\end{array}$ \\
\hline
\end{tabular}

On the other hand, the collocation that occurs most often with the word 'patient' is 'care'. The collocation of the word 'patient' is $518,618(1,847.18$ per million). It can be analyzed for collocation of the accompanying context of the word 'patient' as follows.
The ten samples of collocation of collocation of the word 'care' which follows the word 'patient' can be seen in the table 4 in the next two pages.

As in the collocation of the word 'suspect', the collocate 'care' that follows 'patient' has semantic prosody relation because they occur in a valenced 
context. ${ }^{38}$ It is in line with the statement said by Hauser and Schwarz. The relationship between nodes and their collocation has a meaningful relationship in the semantic field. Based on the the impression of this relation of semantic prosody, it can be seen that the collocate 'care' which follows the word 'patient' has positive context when it has clear advantage from crafting a positive impression. ${ }^{39}$ This is also what Bublitz initiated that "Words can have a specific profile, which may be positive, pleasant and good, or else negative, unpleasant and bad". ${ }^{40}$ Louw even called it a specific term as "aura of meaning". ${ }^{41}$ The impression that appears from the text is further developed by Jaworska and Ryan when they direct the discussion to whose gender is writing and see the emotions that appear in their writing. ${ }^{42}$

The table above shows that the collocate 'care' which follows the word 'patient' has a positive tendency seen from a certain arrangement in the context of sentences in scientific journals from the corpus COVID-19 sketch engine. From the ten data shown in table 4 , the collocation of 'patient' followed by the word 'care', almost all of them indicate

38 David J Hauser and Norbert Schwarz, "How Seemingly Innocuous Words Can Bias Judgment: Semantic Prosody and Impression Formation," Journal of Experimental Social Psychology 75 (2018): 12.

${ }^{39}$ Hauser and Schwarz, 15.

40 Wolfram Bublitz, "Semantic Prosody and Cohesive Company: 'Somewhat Predictable,"' Leuvense Bijdragen 85, no. 1-2 (1995): 9.

${ }^{41}$ Louw, "Irony in the Text or Insincerity in the Writer?," 157.

42 Jaworska and Ryan, "Gender and the Language of Pain in Chronic and Terminal Illness," 111. that the person is hospitalized and should get service. Some even the context in scientific journals related to this collocation shows that people who are sick with any disease, including COVID19, should receive special and intensive services. Therefore, the word 'care' here refers to services that must be received by patients.

According to the Oxford Dictionary, the origin of the word 'patient' itself is Middle English from Old French, from Latin patient- 'suffering', from the verb pati, while the noun has a definition, namely $A$ person receiving or registered to receive medical treatment. This means that 'patient' is itself an ancient French word for suffering which refers to the adjective 'to suffer' and the noun itself refers to someone who is receiving or enrolled in medical treatment. This further confirms the idea that the word 'patient' tends to be positive in semantic prosody. This can also be seen from the collocations which have a high frequency when juxtaposed with the patient. The collocation of 'patient' itself is related to 'service', 'safety', 'management', 'outcome' and contact. Everything that refers to guaranteed care.

Thus, this study has a word token that is more 'patient' than 'suspect'. The word 'patient' indicates a collocation of 518,618 words (1,847.18 per million). Meanwhile, the word 'suspect' shows the collocation of words with the result of 14,505 (51.66 per million). The function of the $\mathrm{Ml}$ score itself is to measure the level of occurrence of significant collocations. The following is a table as evidence of the 
frequency of 'suspect' and 'patient' collocations from a collection of journals on the 2020 sketch engine.

Table 5.

Collocation and MI Score

\begin{tabular}{ll}
\hline Collocation & MI Score \\
\hline Suspect & 14,505 (51.66 per million) \\
Patient & $\begin{array}{l}518,618(1,847.18 \text { per } \\
\text { million })\end{array}$ \\
\hline
\end{tabular}

Based on the table above, these results show the use of COVID-19 data journals on the sketch engine more on the word 'patient'. This is evident from the very significant difference in the number of the two words used. This is based on the comparison of the words 'suspect' and 'patient' based on semantic prosody. The application of semantic prosody is to assess the tendency of a word or phrase, either positive or negative, to be used with concordance analysis.

\section{Conclusion}

Based on the results that have been described, two findings were found in accordance with the author's objectives in conducting this study. The first thing is how the word token from the synonyms 'suspect' and 'patient' is translated in the context of COVID-19. Specifically, the word 'suspect' in the COVID-19 corpus shows a collocation with a result of 14,505 (51.66 per million) and the word 'patient' with a total of $518,618(1,847.18$ per million). This explains directly that the use of data in COVID-19 journals on the sketch engine uses the word 'patient' more than 'suspect'.
The second thing is that the results of the research which are translated from the top word token show that the word that follows 'suspect' for the word 'SARS' has a negative tendency, as well as for the word collocation consisting of 'animal', 'virus', and 'case-patients'. . It can be concluded that the word that follows the 'suspect' has a negative tendency. Meanwhile, the word that follows 'patient' with the highest frequency, namely 'care', has a positive tendency, as is the word for collocation related to 'service', 'safety', 'management', 'outcome' and 'contact'. Everything related to medical care. It can be concluded that the word that follows 'patient' has a collocation with a positive tendency.

\section{References}

Bublitz, Wolfram. "Semantic Prosody and Cohesive Company: 'Somewhat Predictable." Leuvense Bijdragen 85, no. 1-2 (1995): 1-32.

Carroll, David W. Psychology of Language. Belmont: Thomson Learning Academic Resource Center, 2008.

Dam-Jensen, Helle, and Karen Korning Zethsen. "Translator Awareness of Semantic Prosodies." Target. International Journal of Translation Studies 20, no. 2 (2008): 203-21. https://doi.org/10.1075/target.20.2.0 2dam.

Edmonds, Philip, and Graeme Hirst. "Near-Synonymy and Lexical Choice." Computational Linguistics 28, no. 2 (2002): 105-44. https://doi.org/10.1162/0891201027 60173625 .

Glynn, Dylan. "Techniques and Tools: Corpus Methods and Statistics for Semantics." In Corpus Methods for 
Semantics: Quantitative Studies in Polysemy and Synonymy, edited by Dylan Glynn and Justyna A. Robinson. Amsterdam: John Benjamins Publishing Company, 2014.

https://benjamins.com/catalog/hcp.4 3.

Hatch, Evelyn, and Cheryl Brown. Vocabulary, Semantics and Language Education. Cambridge: Cambridge University Press, 1995.

Hauser, David J., and Norbert Schwarz. "How Seemingly Innocuous Words Can Bias Judgment: Semantic Prosody and Impression Formation." Journal of Experimental Social Psychology 75 (2018): 11-18. https://doi.org/10.1016/j.jesp.2017.1 0.012 .

Hunston, Susan. Corpora in Applied Linguistics. Cambridge Applied Linguistics. Cambridge: Cambridge University Press, 2002. https://doi.org/10.1017/CBO978113 9524773.

Islamiyah, Millatul, and Muchamad Sholakhuddin Al Fajri. "Skinny, Slim, dan Thin: Analisis Berbasis Korpus Kata Sifat Identik dan Implikasinya pada Pengajaran Bahasa Inggris." Ranah: Jurnal Kajian Bahasa 8, no. 1 (2019): 19-32. https://doi.org/10.26499/rnh.v8i1.89 4.

Jaworska, Sylvia, and Kath Ryan. "Gender and the Language of Pain in Chronic and Terminal Illness: A Corpus-Based Discourse Analysis of Patients' Narratives." Social Science \& Medicine (1982) 215 (2018): 10714.

https://doi.org/10.1016/j.socscimed. 2018.09.002.

Khazaal, Edhah Numan. "Investigating and Analyzing ESP College Students' Errors in Using Synonyms." International Journal of English Linguistics 9, no. 5 (2019): 328-39.

https://doi.org/10.5539/ijel.v9n5p328.
Koteyko, Nelya. "Corpus Linguistics and the Study of Meaning in Discourse." The Linguistics Journal 1, no. 2 (2006): 132-57.

Kübler, Natalie, and Alexandra Volanschi. "Semantic Prosody and Specialised Translation, or How a Lexico Grammatical Theory of Language Can Help with Specialised Translation." In Studies in Corpus Linguistics, edited by Alex Boulton, Shirley Carter-Thomas, and Elizabeth Rowley-Jolivet, 52:10334. Amsterdam: John Benjamins Publishing Company, 2012. https://doi.org/10.1075/scl.52.05kub.

Louw, Bill. "Irony in the Text or Insincerity in the Writer? - The Diagnostic Potential of Semantic Prosodies." In Text and Technology, edited by Mona Baker, Gill Francis, and Elena Tognini-Bonelli, 157. Amsterdam: John Benjamins Publishing Company, 1993. https://doi.org/10.1075/z.64.11lou.

Nokkonen, Soili. "The Semantic Variation of NEED TO in Four Recent British English Corpora." International Journal of Corpus Linguistics 11, no. 1 (2006): 29-71. https://doi.org/10.1075/ijcl.11.1.03no k.

O'Keeffe, Anne, Michael McCarthy, and Ronald Carter. From Corpus to Classroom: Language Use and Language Teaching. Cambridge: Cambridge University Press, 2007.

Partington, Alan. "'Utterly Content in Each Other's Company': Semantic Prosody and Semantic Preference." International Journal of Corpus Linguistics 9, no. 1 (2004): 131-56. https://doi.org/10.1075/ijcl.9.1.07par.

Quine, W. V. "Main Trends in Recent Philosophy: Two Dogmas of Empiricism." The Philosophical Review 60, no. 1 (1951): 20-43. https://doi.org/10.2307/2181906. 
Retno, Utami. "Kajian Sinonim Nomina dalam Bahasa Indonesia." Master Thesis, Universitas Sebelas Maret Surakarta, 2010.

Salama, Amir H. Y. "Ideological Collocation and the Recontexualization of WahhabiSaudi Islam Post-9/11: A Synergy of Corpus Linguistics and Critical Discourse Analysis." Discourse \& Society 22, no. 3 (2011): 315-42. https://doi.org/10.1177/0957926510 395445.

Sinclair, John. "The Lexical Item.-Edda Weigand (Ed.). Contrastive Lexical Semantics. Current Issues in Linguistic Theory 171." Amsterdam: John Benjamins, 1998.

Sinclair, John. "The Search for Units in a Meaning." Textus IX, 1996, 75-106.

Sinclair, John M. Looking Up: An Account of the COBUILD Project in Lexical Computing. London and Glasgow: HarperCollins, 1996.

Stojchevska, Bisera Kostadinovska. "The Semantic Aspect of the Acquisition of Synonyms, Homonyms and Antonyms in the Teaching Process of English as A Foreign Language." European Journal of Foreign Language Teaching 3, no. 2 (2018): 28-43. https://doi.org/10.5281/zenodo.1216 500.

Storkel, Holly L., and Junko Maekawa. "A Comparison of Homonym and Novel Word Learning: The Role of Phonotactic Probability and Word Frequency." Journal of Child Language 32, no. 4 (2005): 827-53.

Stubbs, Michael. Words and Phrases: Corpus Studies of Lexical Semantics. Oxford: Blackwell Publishing, 2001.
University College London. "Mutations in SARS-CoV-2 Offer Insights into Virus Evolution." UCL News, May 6, 2020.

https://www.ucl.ac.uk/news/2020/ma $\mathrm{y} /$ mutations-sars-cov-2-offerinsights-virus-evolution.

World Health Organization. "Novel Coronavirus (2019-NCOV)." Situation Report, January 20, 2020. https://www.who.int/docs/defaultsource/coronaviruse/situationreports/20200121-sitrep-1-2019ncov.pdf. 